\title{
Egalitarian Liberalism What Are Its Possible Futures in South Africa?
}

Liberalism is associated by many with the protection of private property and the insulation of economic markets from state intervention. Yet the liberal tradition is very diverse, and some have taken its concern with equality and liberty in radically egalitarian directions that belie the reduction of liberalism to market-fundamentalist 'neoliberalism'.

Since its seventeenth-century inception (although the term was only invented in the early nineteenth), liberalism has made necessary points against despotic state power that were vindicated by the late twentieth-century collapse of the Soviet Union and its allied 'Communist' regimes. These points remain pertinent in contemporary South Africa where some argue that realising social justice requires the attenuation of so-called 'bourgeois' liberal rights.

At the same time, liberal thinkers, notably those located within analytic political philosophy, have since the early 1970s (spurred above all by John Rawls's A Theory of Justice) been exploring and developing liberalism's substantively egalitarian possibilities. Egalitarian liberals have in recent decades argued that equality of rights entails more than civil and political rights alone, and must include some variant of substantive economic equality or at least the elimination of poverty, if necessary by steeply redistributive measures. Egalitarian liberals view equality and welfare as enhancing the worth of political and civil liberties to the poor, and in the process as enabling an equal democratic citizenship; but also as desirable in their own right, as matters of justice. Political and civil liberties in turn protect the associational rights of pro-poor movements and provide space for free deliberation about social justice. Some liberal thinkers extend the list of basic rights to include justiciable socio-economic rights.

Despite these promising developments, egalitarian liberalism has barely registered on the South African progressive scene. For various historical reasons, the term 'liberal' has become something of a dirty word in South African progressive lexicon. Even some whose interventions might properly be designated left-liberal, for example in the human rights community, have eschewed this label.

Yet it would be a pity if aversion to the 'l-word' were to divert progressives from the task of defending political and civil liberties in South Africa or deny 
progressives the insights of a sophisticated egalitarian literature. Whether vital liberal rights can be defended without the adoption of the liberal mantle whether indeed liberalism owns them - is one amongst many issues that leftliberals, social democrats and democratic socialists might debate. Again, it is a matter for debate whether a liberal egalitarianism developed primarily in the academic precincts of the Global North has relevance to a Global South characterised by underdevelopment, extreme poverty, state fragility, ethno-cultural complexity and home-grown communitarian traditions.

In October 2014, we organised a conference to engage with the notion of egalitarian liberalism and its possible futures in South Africa. The conference was held at the Constitutional Court of South Africa whose task has been to interpret a constitution which includes both civil and political rights and socioeconomic rights. The political philosophy underpinning the Constitution is itself contested; there is no doubt, however, that the court is tasked with reconciling in a practical manner concerns relating to liberty as well as equality. Arguably, this is one of the key tensions involved in developing a viable form of egalitarian liberalism. The conference sought to stimulate thinking - both supportive and critical - around a number of key questions and engaged academics, members of civil society, and members of parliament and the executive.

First, we sought to consider the current state of debate within political philosophy concerning the possibilities and justification of egalitarian liberalism. Underlying this engagement with the rich literature that has developed, was a key question concerning the value in a South African context of the insights generated by, for example, luck egalitarianism, left libertarianism, prioritarianism and sufficientarianism.

Secondly, we were interested in the more historical question about whether South African liberalism has itself developed a progressive and egalitarian element or whether it has tied itself inextricably to the defence of property. This question involved considering whether there are clear distinctions between an egalitarian form of liberalism and the various socialist traditions that have developed in South Africa.

A third question concerned whether there are inevitable trade-offs between 'first generation' liberal freedoms and urgent development imperatives. Rawls, who defended the 'priority' of liberty, thought there might be some such tradeoff in less developed countries, but others have argued that democratic liberties are vital to securing development at an acceptable human cost (if not development itself). Some argue that democracy is defensible in its own right, irrespective of its developmental benefits. For still others individual freedom is a component of development. Can liberal egalitarianism rebut those who regard political and civil liberties as luxuries or as instruments of privilege?

A fourth line of enquiry surrounds the place of socio-economic rights in liberal thought and in the struggle for social justice. Though modern liberals are democrats, many liberals would place certain areas of decision-making out of the reach of legislative majorities. So-called 'negative' freedoms are 
classically placed within this range, often for reasons to do with the defence of democracy itself (as, say, with voting rights); but some egalitarian liberals would also place socio-economic rights within this category. This raises questions about the proper scope of these rights and how much power should be accorded to judges in giving them specific policy content.

A rich range of papers was presented at the conference, some of which we are pleased to be able to share with a wider audience in the form of this special edition of Theoria. The edition commences with an essay from the eminent historian Saul Dubow who considers whether there can be said to be an egalitarian liberal tradition in South Africa. Dubow recognises that there is a long South African liberal tradition, which has had a range of diverse influences. It is, he writes, impossible to define South African liberalism definitively 'given the longevity of the South African liberal tradition as well as the shifting, situationally defined contexts in which it can be found'. Liberalism in South Africa, he recognises, had an element that promoted unbridled laissez-faire capitalism but that was in fact a minority position. He finds rather that a significant strand in the liberal tradition was well disposed to redistributive mechanisms. Whilst liberals supported the protection of private property rights, there was a recognition of the need for equality of opportunity. State intervention was understood to be necessary to correct the wrongs of the past and allow individuals to compete on an equal basis. Many liberals recognised that '[i]n a society so markedly divided along lines of race and class, some commitment to egalitarianism is a political requirement in order to redress the inequities of apartheid'.

Daryl Glaser sets himself the challenging task of defining what demarcates the contours of liberal egalitarianism. Such a project requires accommodating diverse particular theories of justice whilst tracking their similarities. Glaser contends that liberal egalitarianism must involve the simultaneous strong defence of individual liberty and substantive equality. Yet, since there are tensions and contradictions between these two sets of concerns, differing liberalegalitarian theories address them in divergent ways. Despite this, Glaser attempts to specify a key set of commitments which liberal egalitarians share: that property rights are weak and must often 'yield in order to resolve certain inevitable liberty-equality tensions'; that civil liberties are protected against trade-offs for distributional equality gains; that robust socio-economic rights are defensible and perhaps mandatory in egalitarian-liberal terms yet require appropriate and democracy-sensitive delimitation; and that a liberal-egalitarian democratic theory must respect a certain minimum of proceduralism within its account of democracy even while conjoining this proceduralist minimum to a substantive and strong theory of equality and justice. These diverse commitments remain objects of an ongoing debate among egalitarian liberals and yet a source of its claim to constitute an attractive value combination.

David Bilchitz is also concerned with understanding the commonalities in egalitarian liberal theories but focuses his analysis on the underlying structure 
of these theories. He is concerned to understand the implications of egalitarian liberalism for modern constitutions in the Global South which enshrine rights and values relating both to equality and liberty. In his article, Bilchitz outlines what he terms a two-tier structure of theories of distributive justice. This structure involves there being a certain distribution of resources that must be achieved and guaranteed equally for all (which can be referred to as the firsttier). Beyond this threshold or pattern, in the second tier, resource variation must be allowed. The two-tier structure faces challenges in articulating the first threshold with sufficient precision as well as keeping the tiers distinct. Bilchitz attempts to show the manner in which two leading theories of distributive justice - those of Ronald Dworkin and John Rawls - reflect the two-tier structure and the resources they have to address the difficulties thereof. He then proceeds to argue that the two-tier structure helps explain, reconcile and develop key features of the modern democratic constitutions of the Global South. A particularly striking claim is the argument that the structure of distributive justice has particular implications for the relative role of constitutional courts and representative institutions.

Richard Calland also situates his discussion in the context of developing countries and questions the extent to which the right of access to information can be understood in egalitarian liberal terms. The right itself, Calland recognises, is traditionally understood in liberal terms as a freedom intimately connected to freedom of expression and which is justified in terms of its ability to protect citizens against the abuse of state power. However, Calland argues that the right itself need not be circumscribed to such limited purposes: through the use of empirical examples drawn from India and South Africa, he seeks to show the potential of this right to realise substantively egalitarian purposes. For instance, civil society organisations have been able to use it as a 'leverage right' and to make gains for the socio-economic rights of very poor communities. The right thus becomes one that helps 'prevent state power from being used other than for transformative purposes and to help steer the state in the direction of its progressive mandate'. For it to function in this manner, Calland argues four conditions must be met: the political nature of the right must be recognised; legal formalism must be eschewed; the right must apply to privately held information as well as information held by public bodies; and the right should be recognised as a 'power' and 'leverage' right rather than simply as protecting individuals against the abuse of state power.

Finally, Peter Hudson adopts a more critical approach to egalitarian liberalism. He contrasts liberal democracy and national democracy and contends that each has a 'tilt' or ideological commitment towards which it tends. According to Hudson, liberalism - both egalitarian and libertarian versions place as much value as possible on the domain of individual sovereignty and the separateness of persons. Liberals of all kinds are thus uncomfortable with democracy, which requires decision-making by numerical majorities, and thus seek to narrow the space of democratic decision-making as much as possible. 
Liberal democracy thus subordinates the democratic to the liberal in the form of restrictions on what the collective may do: Hudson is particularly concerned about the impact of constitutional property clauses, which limit the distributive ability of the state. In national democracy, 'the sovereignty of the Collective is prioritised over the individual'. The collective may appropriate property assets as it wishes to intervene in the redress of historical wrongs relating, in the South African case, to colonialism and apartheid. Hudson ends his analysis by considering the South African constitution and arguing that the property clause itself 'tilts' the political community towards liberal democracy rather than national democracy.

The articles in this collection communicate a shared concern with social justice and greater equality, whether conceived in individual or - as in Hudson's case - racial terms. They nevertheless exhibit varying degrees of enthusiasm for the liberal project itself, with Glaser perhaps most notably enthusiastic and Calland and Hudson the most sceptical about whether liberalism is capable of delivering the kinds of radically transformative and redistributive measures required by South Africa's inheritance of gross racial and class inequality. Hudson is also doubtful about whether the current constitutional framework is sufficiently transformative. Calland and Bilchitz could be read as challenging this point, recognising the value tensions that exist within the South African Constitution while arguing that it allows for the achievement of significant egalitarian aims together with liberal rights. It is clear from Dubow's article that South Africa's liberal inheritance is itself characterised by internal tensions, and is not reducible to neoliberalism; yet it is also clear from his survey that South African liberalism has not yet finished the task of articulating a theoretically explicit and coherent defence of a genuinely egalitarian liberalism.

As can be seen, the articles in this special edition contribute a rich range of arguments that can help clarify and develop what an egalitarian liberalism in South Africa would look like. South Africa's constitutional order continues to be committed to ensuring liberal freedoms are respected whilst seeking to achieve large-scale social reform in the distribution of wealth in the society. This project is necessary for both reasons of correcting the wrongs of the past and ensuring a just distribution to enable all individuals to be treated with equal worth; and it seeks to accomplish its goals in ways that are respectful of essential human freedoms. The project of articulating an attractive theory of justice for the country is a continuing one that must engage all members of the South African community: we hope this volume will contribute some ideas to this debate and enrich this continuing conversation.

We would like to thank a number of institutions and individuals for their assistance in the conference in October 2013 as well as in the production of this special edition. The conference was a joint venture between the South African Institute for Advanced Constitutional, Public, Human Rights and International Law (SAIFAC, a Centre of the Faculty of Law, University of 
Johannesburg) and the Department of Political Science, University of the Witwatersrand. We thank all those in these institutions for their support. The conference itself was generously supported financially by the Konrad Adenauer Stiftung and we thank Dr Holger Dix as well as Nancy Msibi for their continuing support for developing the spaces of public engagement around important ideas in South Africa. Dolores Joseph provided invaluable administrative assistance and we thank her as well as Vusi Ncube for his logistical help on the day. Lara Engelbrecht (Faculty of Law, UJ) gave creative input into marketing the conference and we thank her for that. Finally, we would like to thank the editorial board of Theoria for agreeing to this special edition and their work in ensuring it saw the light of day. In particular, we greatly appreciate the work of the managing editors Christopher Allsobrook and Sherran Clarence in ensuring this special edition came to fruition. We would also like to thank each other for a very fruitful and enjoyable collaboration.

David Bilchitz and Daryl Glaser

Guest Editors 